Reprod. Nutr. Dévelop., 1982, 22 (6), 1035-1047.

\title{
Ovarian follicular populations in pony and saddle-type mares
}

\author{
M.-A. DRIANCOURT, A. PARIS, Colette ROUX $(*)$, J.-C. MARIANA, E. PALMER
}

Station de Physiologie de la Reproduction, I.N.R.A., Nouzilly, 37380 Monnaie, France.

(*) Service de Biométrie, I.N.R.A., 78350 Jouy-en-Josas. 78350 Jouy-en-Josas, France.

Summary. Five pony and 5 saddle-type mares were used to compare total ovarian follicular populations between breeds. The animals were hemi-ovariectomized at the preovulatory stage during the breeding season and the ovary bearing the large preovulatory follicle was studied using histological techniques.

Pony and saddle-type mares did not differ as to mean number of primordial follicles, mean number of growing follicles, the variability of these numbers and follicular distribution into various size classes.

No difference was detected either in the initiation processes of follicular growth, oocyte growth, granulosa cell multiplication and follicular atresia. However, significant differences were found in the pattern of antral formation $(P<0.01)$.

The present data suggest that pony mares are a valuable tool for the study of follicular populations in equines.

The main features of the equine ovary are the small number of follicles (35950 primordial and 100 growing follicles) and the high individual variability of this number (5600 to 75000 primordial and 20 to 300 growing follicles).

\section{Introduction.}

Pony mares are widely used to study ovarian activity in equines. Nevertheless, some differences between pony and saddle-type mares have been reported, such as :

1) the length of the breeding season: the ovulatory estrous cycles of pony mares start later (May vs March) and stop earlier (September vs end of October) than those of large mares (Ginther, 1974 ; Sharp, 1976) ;

2) the length of the estrous cycles: the average values (Ginther, 1979) are 25 days for pony mares and 22.7 days for large mares ;

3) the occurrence of multiple ovulations : according to Ginther (1979), these are quite rare in pony mares $(2 \%)$, while their mean frequency increases in large mares $(16 \%)$;

4) the occurrence of seasonal anestrus : $100 \%$ of pony mares are in anestrus during the winter but this is true for only $60 \%$ of large mares (Palmer, 1978). 
Numerous reports have shown differences in total follicular populations between breeds (ewe : Cahill, Mariana and Mauléon, 1979; Kassi-Lahlou and Mariana, unpublished) or strains (de Reviers and Terqui, 1976) which lead to differences in ovarian activity.

The aim of the present work was (1) to compare follicular development and follicular populations in pony and saddle-type mares and (2) to study the intraovarian relationship of these populations in the ovary.

\section{Material and methods.}

Animals. - We used 5 pony and 5 saddle-type mares, weighing 250 to $320 \mathrm{~kg}$ and 500 to $600 \mathrm{~kg}$, respectively, which were 2 to 4 years old and in good physical condition.

At the beginning of the breeding season (May 15 to June 15), all the animals were hemi-ovariectomized at the preovulatory stage which was assessed by rectal palpation: (Nishikawa, 1959) and echographic examination (Palmer and Driancourt, 1980). As the follicular populations in both ovaries are known to be very similar lewe: Cahill, Mariana and Mauléon, 1979; Kassi-Lahlou and Mariana, unpublished ; mare : Driancourt, Mariana and Palmer, 1982), only one ovary per animal was studied.

Histological methods. - Immediately after removal, the ovaries were fixed in Bouin-Hollande's solution. They were then cut into serial sections $10-\mu \mathrm{m}$ thick; one section out of five was mounted, stained with hematoxylin and examined microscopically. The nucleus of the oocyte was used as a marker to avoid counting the follicles twice. However, owing to sampling, it was often invisible ; therefore, the first and last sections were regarded as the extremities of the follicle, and measurements were taken on the section that lay midway between these extremities.

Follicular counting. - According to Mariana (1972), the follicular population can be divided into two parts, the pool of primordial follicles (ie those without a complete cuboidal cell layer and having an area smaller than $2000 \mu \mathrm{m}^{2}$ ) and growing follicles (having an area larger than $2000 \mu \mathrm{m}^{2}$ ).

a) Estimation of the parameters of the primordial follicle population. - We developed a sampling procedure for obtaining a quick, exact estimate of the number of primordial follicles. All the primordial follicles on all the mounted sections of the half ovaries of two anestrous pony mares were counted. The confidence limits $(P=0.05)$ were then calculated for the sampling ratios of the mounted sections ranging from $1 / 10$ to $1 / 40$. As expected, the confidence limits widened as the sampling ratio increased (fig. 1). For a sampling ratio of $1 / 20$ and for ovaries with 10500 and 68000 follicles, the confidence limits were \pm 1550 and \pm 6850 , respectively. As the error of this sampling ratio was small (compared to variations between the different mares in all the ovaries studied), that ratio was selected for counting the number of primordial follicles per ovary. 
To investigate the initiation of follicular growth, we measured the area of the oocyte nucleus, the follicular area and the number of granulosa cells surrounding the oocyte. These parameters were measured on 50 primordial follicles per ovary when the total number of such follicles was over 20000 and on 25 primordial follicles when this number was less.

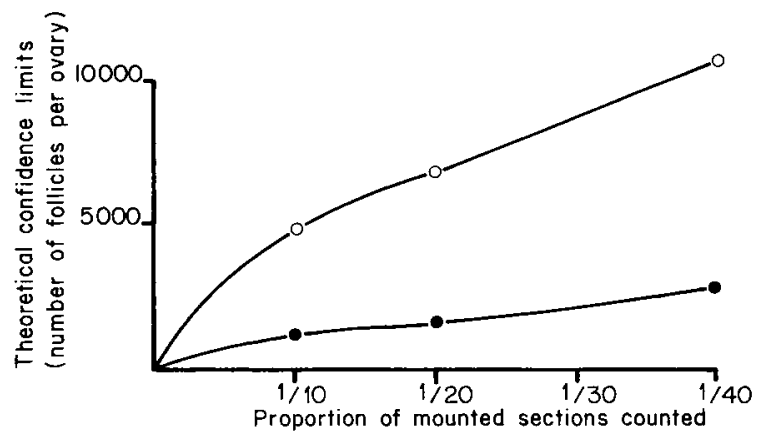

FIG. 1. - Confidence limits $(P=0.05)$ in the estimation of the total number of primordial follicles in two pony ovaries.

b) Estimation of the parameters of the large follicle population. - Using an image analysis system (ASM Leitz), we measured for each follicle the area of the follicle, the area of the oocyte when its nucleus was visible and the area of the antrum. However, to conform to the conventional way of expressing follicular size by a mean diameter, the profile of the follicle was assumed to be circular, and the diameter was calculated and expressed in $\mu \mathrm{m}$.

Furthermore, all follicles were checked for atresia ; a follicle was considered to be atretic when more than five pyknotic nuclei were counted on the section studied (stage I: early atresia). Two later stages were defined according to Kenney et al. (1979) : stage II (advanced atresia), when pyknosis was widespread and numerous granulosa cells floated in the antrum, and stage III (late atresia) in which granulosa was completely lacking, except in the oocyte area. The terminal stages when fibroblasts invaded the follicle were not counted. Contrary to other studies (Gougeon, 1981 ; Monniaux and Gibson, unpublished), irregularly shaped follicles (seldom seen in the-mare) were not considered as atretic.

In all healthy follicles, we determined the number of granulosa cells per follicle in the section studied by either direct counting (follicles smaller than $120 \mu \mathrm{m}$ in diameter) or indirectly ; in larger follicles, this number was calculated as the product of the area the cells occupied and their cellular density measured at ten different points on the follicle using a circular reticle.

All cells undergoing mitosis were counted in the same section, and the mitotic index was obtained by dividing the number of cells in mitosis by the total number of granulosa cells. To show the interbreed differences in mitotic index, a weighted mean and its standard deviation were calculated according to Meier (1953). 
Statistical methods. - The follicles were classified using the area of the follicle as a criterion (de Reviers and Mauléon, 1979). Twelve sub-classes were defined, starting at $2000 \mu \mathrm{m}^{2}$ of area and increasing in geometric progression. These arbitrary sub-classes were further grouped into five main classes according to both the vicinity relationships, found using factorial analysis of correspondance (fig. 2) (Lebart and Fénelon, 1971), and morphological events (see results). The five classes thus determined were : initiated follicles (50 to $125 \mu \mathrm{m}$ in diameter), preantral follicles (125 to $300 \mu \mathrm{m}$ in diameter), small antral follicles $(300$ to $1200 \mu \mathrm{m}$ in diameter), medium antral follicles (1200 to $11000 \mu \mathrm{m}$ in diameter) and large antral follicles (more than $11000 \mu \mathrm{m}$ in diameter).

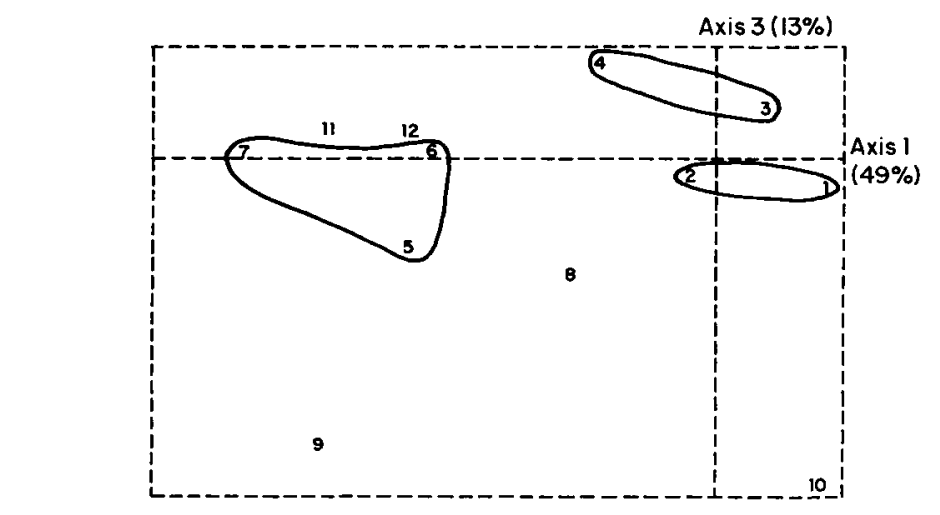

FIG. 2. - Projection on axes 1 and 3 of the factorial analysis of correspondance of the 12 sub-classes used.

Owing to the small number of animals, we used the following nonparametric tests (Siegel, 1956) : the Mann-Whitney U-test to compare the mean numbers of follicles, the Kruskal-Wallis one-way analysis of variance to compare primordial follicle parameters between animals, and the Spearman and Kendall rank correlation coefficients to determine the intraovarian relationships. Differences in linear regression were analyzed according to Dagnelie (1975). To determine the differences in mitotic index, we used an analysis of variance after angular transformation of the percentages.

\section{Results.}

Morphological events of follicular growth.

Initiation of follicular growth. - The changes involved in the initiation of follicular growth have been investigated by plotting the oocyte nuclear area with the follicular area (fig. 3) and the number of granulosa cells (fig. 4). As no breed effect was noted, the data from randomly chosen animals of both breeds have been presented. 


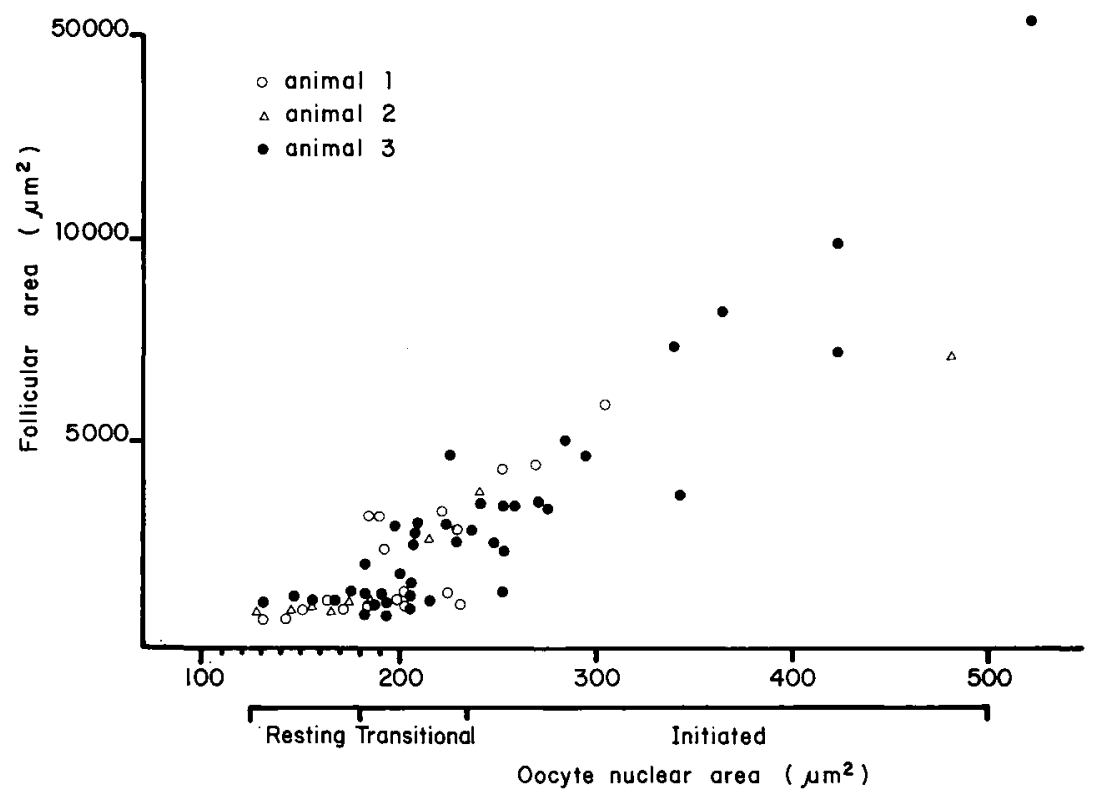

FIG. 3. - The relationship between the oocyte nuclear area and the follicular area. For the resting follicles, each point represents the mean of a given oocyte nuclear area in the follicles of three mares. For larger follicles, each point is a follicle.

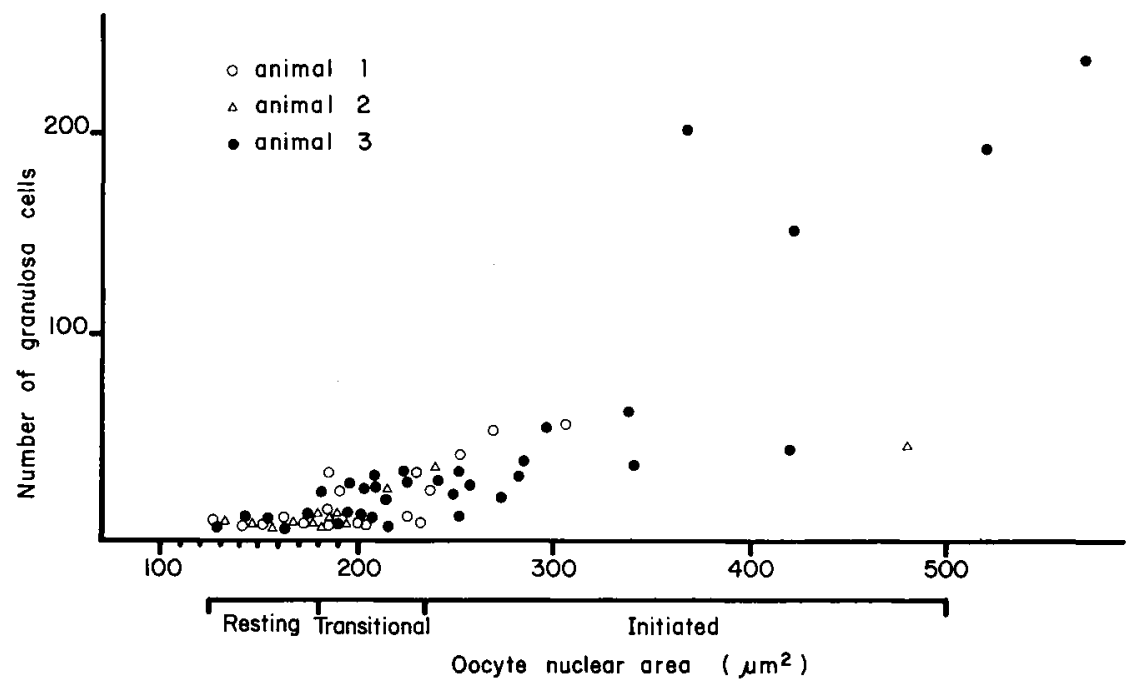

FIG. 4. - The relationship between the oocyte nuclear area and the number of granulosa cells. For the resting follicles, each point represents the mean of a given oocyte nuclear area in the follicles of the same three mares as in figure 3 . For larger follicles, each point is a follicle. 
The follicles smaller than $2000 \mu \mathrm{m}^{2}$ were clearly heterogeneous. Follicles with an oocyte nuclear area smaller than $180 \mu \mathrm{m}^{2}$ were called « resting » follicles. In such follicles, there was little change in follicular size or granulosa cell number per increase in oocyte nuclear area.

Follicles with an oocyte nuclear area between 180 and $250 \mu \mathrm{m}^{2}$ were called " transitional " follicles. They possibly formed a transitional population between the resting and the growing follicles (i. e. those with an oocyte nuclear area exceeding $250 \mu \mathrm{m}^{2}$ and a follicular area larger than $\left.2000 \mu \mathrm{m}^{2}\right)$. In most of these follicles we noted coincident increases in the follicular area and the oocyte nuclear area on the one hand, and in the number of granulosa cells and the oocyte nuclear area on the other.

Four to 44 p. 100 of the primordial follicles were transitional, depending on the animal but not on the breed.

Formation of the antrum. - In both breeds, antral formation began when the follicle reached between 200 and $360 \mu \mathrm{m}$ in diameter. There were no breed differences in either the size of the largest follicle without antrum $(P>0.05)$ or the size of the smallest follicle with an antrum $(P>0.05)$.

However, a more accurate estimate of the beginning of antral formation was obtained from the regression lines linking the follicular area $(x)$ and the antral area $(y)$. These were $y=0.88 x-80371$ for pony $(r=0.99, n=33)$ and $y=0.81 x-53922$ for large mares $(r=0.99, n=27)$. By extrapolation of these regression lines, antral formation was found to begin at a follicular diameter of 340 and $290 \mu \mathrm{m}$ in pony and large mares, respectively (fig. 5). Furthermore, the slopes of these regression line differed significantly $(t=3.57$ $56 \mathrm{df}, \mathrm{P}<0.01$ ).

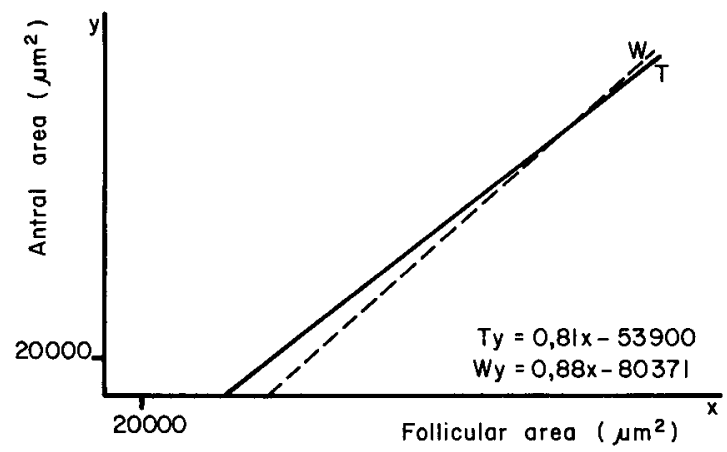

FIG. 5. - The regression lines linking the follicular area and the antral area in pony (W) and saddle-type (T) mares.

Granulosa cell multiplication. - The mitotic index curves of both breeds (fig. 6) clearly show the same pattern for pony and large mares. In initiated follicles, the mitotic index was very low (less than $0.1 \mathrm{p} .100$ ) ; it increased sharply in preantral follicles to reach $0.8 \mathrm{p}$. 100 and stayed at this value in small antral follicles. However, in medium antral follicles, there was a significant 
difference $(F=19, P<0.01)$ between breeds : pony mares had a peak of mitotic activity $(1.3$ p. 100$)$, while large mares remained at about 0.6 p. 100. Nevertheless, owing to a higher cellular density and a larger granulosa cell area in large mares, the previous difference was no longer significant when the mitotic index was plotted against the number of granulosa cells. Due to the small number of healthy large and preovulatory follicles per animal, the two breeds were grouped together, obtaining a mean value of 0.1 to $0.2 \mathrm{p} .100$.

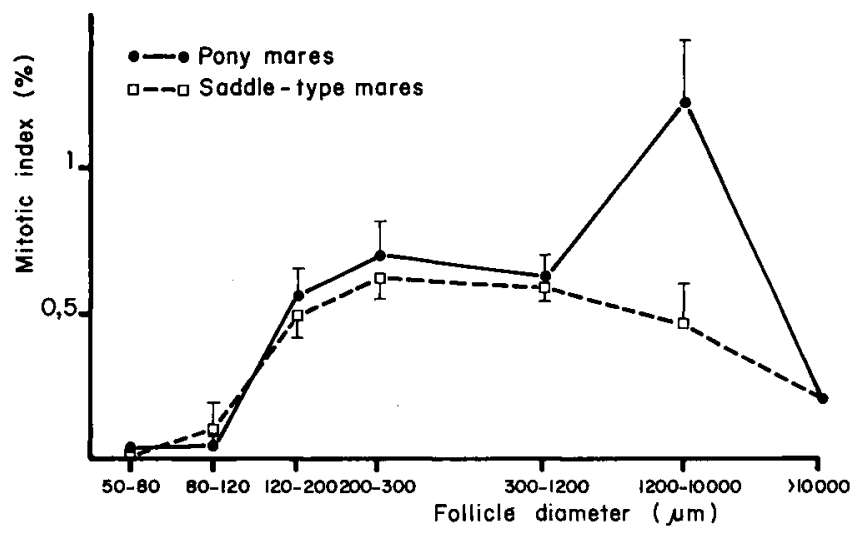

FIG. 6. - The mean mitotic indices for various follicular classes in the ovaries of 5 pony (W) and 5 saddle-type (T) mares.

Thecal cell differentiation. - A well defined theca was not detected in follicles smaller than $130 \mu \mathrm{m}$ in diameter. However, all follicles larger than $200 \mu \mathrm{m}$ in diameter presented a clear thecal layer.

In the larger healthy follicles, three types of theca interna layer were defined on the basis of their cellular compounds : 1) smooth theca (ph. 1), the only type found in follicles smaller than $5000 \mu \mathrm{m}$ in diameter and noticeable in large nonovulatory follicles ; 2) mixed theca (ph. 2), consisting of a smooth layer with islands of large luteal-like cells. Such a theca was seen in about $70 \mathrm{p} .100$ of the follicles with a diameter between 5000 and $10000 \mu \mathrm{m}$;3) hypertrophied theca (ph. 3) composed of a thick layer of luteal-like cells; this theca was only found in preovulatory follicles.

\section{Between-breed comparison of follicular populations.}

Number of follicles. - Owing to a wide variability, no breed effect was detected in the number of primordial follicles (ponies : 10400 to 50400 ; mares : 6400 to 75200 ) or growing follicles (ponies : 37 to 300 ; mares : 20 to 152) per ovary (fig. 7).

Further studies on the population of growing follicles led to similar conclusions (fig. 7): whatever the size class, there were no significant differences between pony and saddle-type mares. 

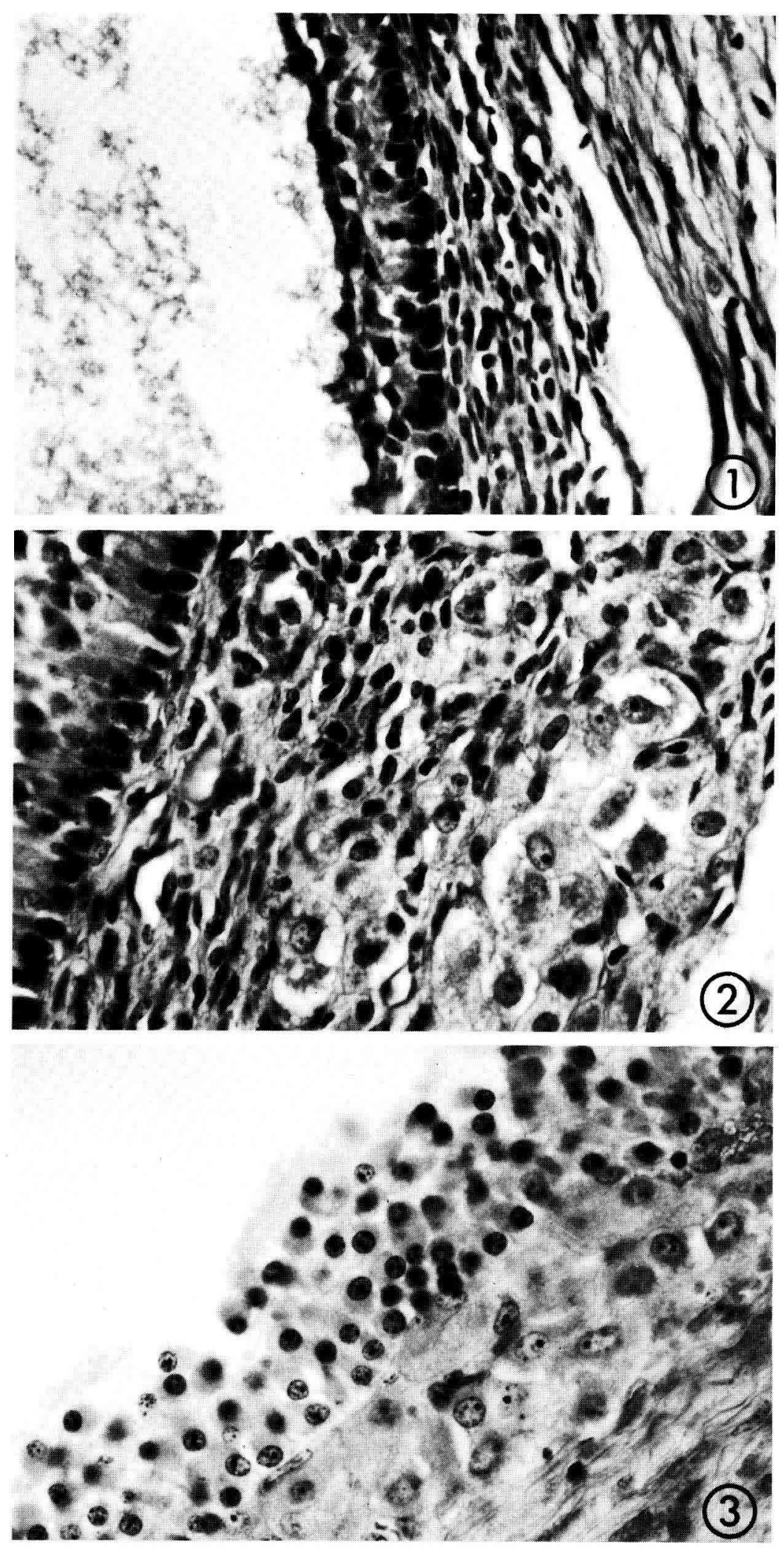


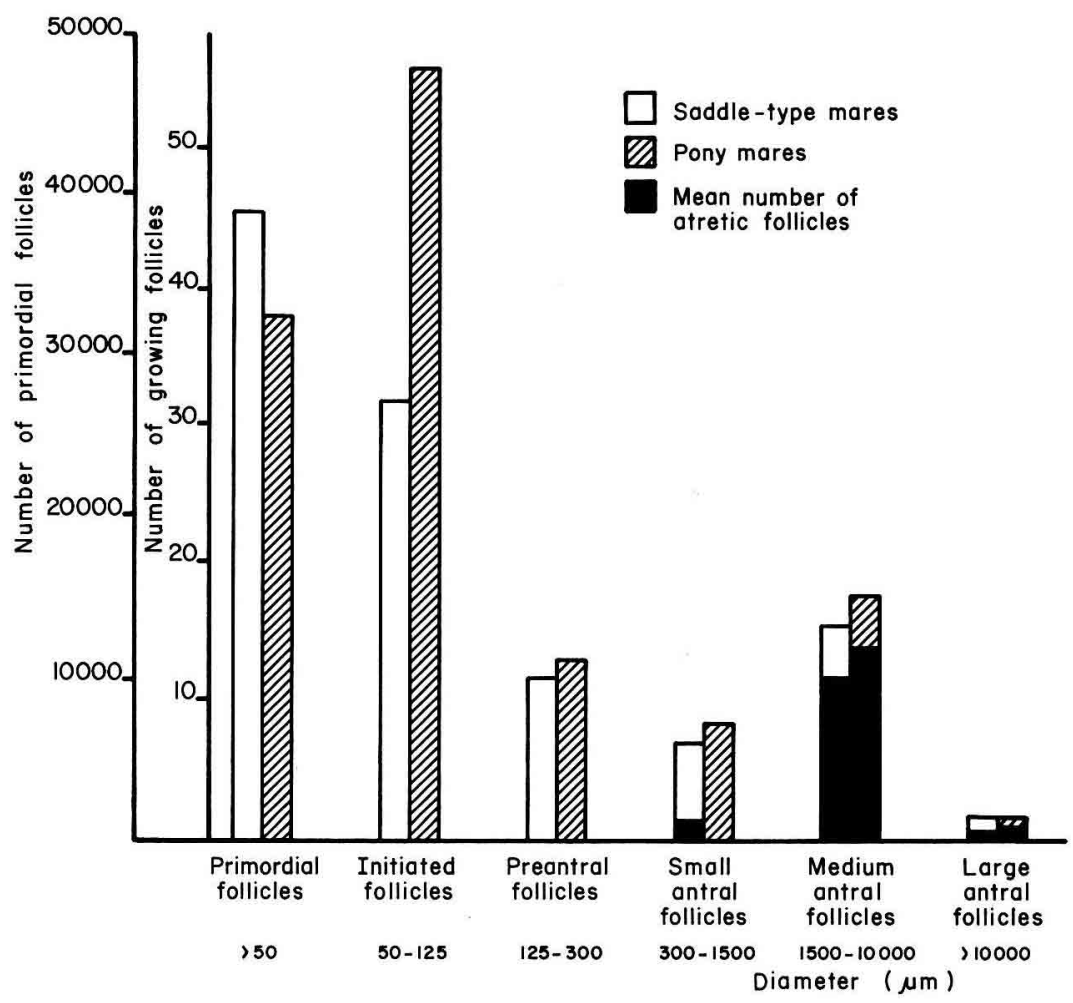

FIG. 7. - The mean number of primordial and growing (healty plus atretic) follicles of various size classes in pony and saddle-type mares.

Follicular distribution into size class. - Comparative studies of follicular distribution into size class, using the $2 \mathrm{I}$ test have shown the lack of intrabreed homogeneity : the same heterogeneity was found for each breed $(2 \mathrm{I}=136$ for pony mares and $2 \mathrm{I}=109$ for large mares, $\chi^{2}=74.5$ ).

Atresia. - With our criterion, atresia was rarely seen prior to medium antral follicles : the percentage of atresia in small antral follicles ranged between 0 and 20 p. 100 for pony and between 0 and 50 p. 100 for large mares. But the

PHOTO 1. - Smooth thecal layer of flattened cells in a follicle $2 \mathrm{~mm}$ in diameter. $\times 320$.

PHOTO 2. - Mixed theca. Flattened cells and hypertrophied luteal-like cells are both present in the theca of this $8-\mathrm{mm}$ follicle. $\times 320$.

PHOTO 3. - Thecal layer of numerous /uteal-like cells in a preovulatory follicle $33 \mathrm{~mm}$ in diameter. $\times 320$. 
highest proportion of atresia was seen in medium antral follicles, 75 and 70 p. 100 of which were atretic in pony and large mares, respectively. The percentage of atresia was not calculated for larger follicles due to the small number of follicles in this size class. Comparative studies of the extent of atresia between the two breeds did not reveal any difference. Furthermore, follicular distribution into the different stages of atresia did not differ between breeds.

Intraovarian relationships. - As no significant differences were found in : - the total number of follicles or the number of follicles per size class ; - follicular distribution into different size classes : - the extent of atresia, all the ovaries were pooled to study intraovarian relationships.

The exit of the primordial pool was studied by examining the relationship between its two components (resting and transitional follicles) and the smaller growing follicles (initiated follicles). Whatever the size class considered, there was no significant relationship with the number of resting primordial follicles. On the contrary, a significant correlation $(r=0.57, P<0.05)$ was evident between the number of transitional and smaller initiated (sub-class 1) follicles.

Strict correlations in the growing follicle population, that is correlations not modified by the removal of other classes, were detected by calculating the Kendall partial rank correlation coefficients linking the number of healthy and early atretic follicles in the different size classes (fig. 8).

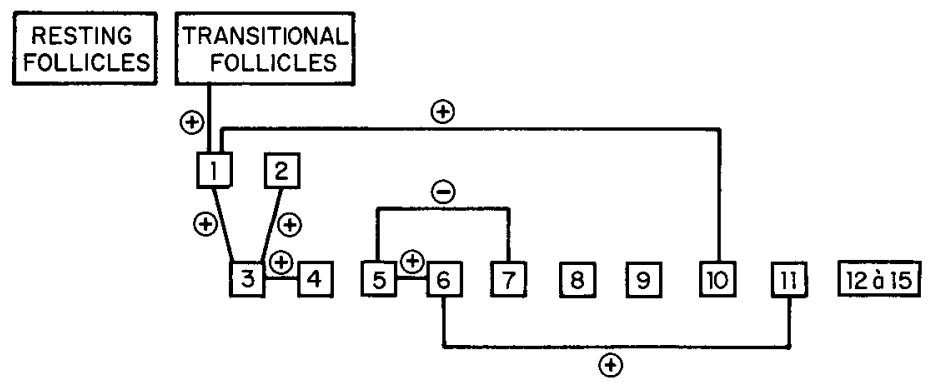

FIG. 8. - Intraovarian correlations between size classes.

On the basis of their value, three groups were established; sub-classes 1 to 4, 5 to 11 and 12 corresponded, respectively, to initiated and preantral, small and medium antral and large antral classes. Within the sub-classes 1 to 4 it should be noted that classes 1 and 2 were not correlated, while each was correlated to class 3 .

Further studies designed to evidence a link between the mean value of the mitotic index in a class and the number of follicles in that class were carried out using Spearman rank correlation in initiated, preantral and small antral follicles ; whatever the size class, no significant correlation was found between follicular number and mitotic index $(r=0.38$ for initiated, $r=0.35$ for preantral and $r=0.11$ for small antral follicles). 


\section{Discussion.}

The follicular development in pony and saddle-type mares presents closes similarities.

The initiation of follicular growth, the multiplication of granulosa cells and the extent of atresia do not differ between these two breeds. The same conclusions have been reported in various breeds of sheep for the last two parameters (Romanov and Ile-de-France: Cahill, Mariana and Mauléon, 1979 ; Booroola and Merinos : Cahill and Turnbull, personal communication). The only difference found in the present study concerns antral formation, which occurred at an earlier stage of growth and was followed by a slower development in large mares than in ponies. As FSH is known for its ability to initiate antral formation and development (Evans et al., 1939), this might be linked either to breed differences in FSH secretion or to a pattern in the development of FSH receptivity which is particular to each breed.

Furthermore, as we could not demonstrate any difference between breeds as to the number of follicles per size class or to the distribution of follicles in size classes, it is likely that differences in ovarian activity arise from inter-breed differences in hormonal patterns.

Thus the two breeds were pooled to study the relationships between these size classes.

Follicular growth was initiated from a reserve of small follicles of three types :

1) resting follicles which did not seem to play a basic role, as shown by the lack of correlation between their number and the number of follicles found in other classes :

2) transitional follicles which are a key group as their number is significantly related to the number of smaller initiated follicles. It is not known if these follicles are formed at a given time of oogenesis or originate from a particular part of the ovary, or what induces the high inter-animal variability in their number ;

3) initiated follicles which probably belong to the reserve of small follicles since there is no correlation between the smaller and the larger initiated follicles, while each of these groups is related to the preantral group, and since their number is high while their mitotic index is almost zero.

In conclusion a three compartments model could fit initiation of follicular growth in the equine. This hypothesis is supported by the data of Mariana and Meyer (1979) using simulation studies to demonstrate the same pattern of initiation in the rat. Furthermore, the heterogeneity of the small follicle reserve has already been demonstrated in other species by morphological (Cahill and Mauléon, 1981) or physiological (Mariana, 1978) data.

It is noteworthy that, contrary to what has been suggested for ewes (Cahill and Mauléon, 1980), we found no relationships between the mitotic index and the number of follicles in a class, in agreement with studies on cow ovaries 
(Monniaux, personal communication). Also, it should be noted that there is a lack of correlation between the numbers of medium antral and large antral follicles, indicating the strong control exerted by feedback mechanisms on these large antral follicles.

More generally, folliculogenesis in the equine is original due to the low number of follicles involved: in our young animals there were only 35000 primordial and 100 growing follicles. This was demonstrated by comparison with the follicular populations of other species. In the cow ovary, 120000 primordial (Erickson, 1966) and 280 to 435 growing follicles (Erickson, 1966 ; Monniaux, personal communication) have been found. In the lle-de-France ewe, Cahill, Mariana and Mauléon (1979) counted 56000 primordial and 150 growing follicles. The small number of follicles available in equines raises two questions. (1) is this low number related to oogenesis or is it a consequence of the particular morphogenesis of the equine ovary during the postnatal period, leading to the formation of the ovulation fossa (Walt et al., 1979) ? The examination at birth of ovaries presenting a large number of follicles (Driancourt, unpublished) suggests that the second possibility is very likely; $(2)$ is there a relationship between this low level of folliculogenesis and the low response to a superovulatory stimulus? When pituitary extracts are used (but not at the same dose), the mean number of induced ovulations is about 3 in mares (Woods, Scraba and Ginther, 1982) and around 20 in cows (Chupin, personal communication).

Nevertheless, despite the small number of follicles in the equine, ovulation occurs regularly, even with populations as low as 20 growing follicles per ovary. Such a population was present in one of the mares studied, showing that the minimal level of folliculogenesis needed for ovulation is very low.

Reçu en janvier 1982. Accepté en août 1982.

Résumé. Populations folliculaires de l'ovaire équin.

Cinq ponettes et 5 juments de selle ont été utilisées pour réaliser une comparaison des populations folliculaires. Toutes ont été hémicastrées en début de saison sexuelle, au stade préovulatoire et l'ovaire portant le gros follicule a été étudié en histologie classique.

II n'existe pas de différences raciales pour le nombre de follicules primordiaux, le nombre de follicules en croissance, la variabilité de ces nombres et la distribution des follicules dans les différentes classes de taille.

De même, pour certains paramètres morphologiques, telles l'initiation de la croissance, la croissance de l'ovocyte, l'évolution de l'index mitotique avec la taille et l'importance de l'atrésie, les deux races sont similaires. Par contre, le développement de l'antrum est plus précoce et plus lent chez les juments de selle. Cette exception mise à part, les ponettes sont un bon modèle expérimental pour étudier la folliculogenèse équine.

Les principales caractéristiques de l'ovaire équin sont la faiblesse des effectifs folliculaires (35 950 primordiaux et 100 follicules en croissance) et l'importante variabilité de ces effectifs (5600 à 75000 follicules primordiaux, 20 à 300 follicules en croissance). 


\section{References}

CAHILL L. P., MAULEON P., 1980. Influences of season, cycle and breed on follicular growth rates in sheep. J. Reprod. Fert., 58, 321-328.

CAHILL L. P., MAULÉON P., 1981. A study of the population of primordial and small follicles in sheep. J. Reprod. Fert., 61, 201-206.

CAHILL L. P., MARIANA J. C., MAULEON P., 1979. Total follicular populations in ewes of high and low ovulation rates. J. Reprod. Fert., 55, 27-36.

DAGNELIE P., 1975. Analyse statistique à plusieurs variables. Les Presses agronomiques. Gembloux.

DRIANCOURT M. A., MARIANA J. C., PALMER E., 1982. Effect of stage of œstrus cycle on the follicular population in pony mares. Reprod. Nutr. Dévelop., 22 (in press).

ERICKSON B. H., 1966. Development and senescence of the postnatal bovine ovary. J. anim. Sci., 23, $800-805$.

EVANS H. M., SIMPSON M. E., TOLKSDORF S., GENSEN H., 1939. Biological studies of the gonadotrophic principles in sheep pituitary. Endocrinology, 25, 529-546.

GINTHER O. J., 1974. Occurrence of anoestrus, oestrus, dioestrus and ovulation over a 13 month period in mares. Am. J. vet. Res., 35, 1173-1174.

GINTHER O. J., 1979. Reproductive biology of the mare: basic and applied aspects. McNaughton \& Gunn, Ann Arbor, Mich.

GOUGEON A., 1981. Cinétique de la croissance et de l'involution des follicules ovariens pendant le cycle menstrue/ chez la femme. Th. Doct. Etat ès Sci. nat., Univ. Paris VI.

KENNEY R. M., CONDON W., GANJAN V. K., CHANNING C. P., 1979. Morphological and biochemical correlates of equine ovarian follicles as a function of their state of viability or atresia. J. Reprod. Fert., Suppl. 27, 163-171.

LEBART L., FÉNELON J. P., 1971. Statistique et informatique appliquées. Dunod, Paris.

MARIANA J. C., 1972. Classification des follicules ovariens. Principes et méthodes d'étude Ann. Biol. anim. Bioch. Biophys., 12, 377-385.

MARIANA J. C., 1978. Analyse biométrique de l'index de marquage des cellules folliculeuses et de la taille des ovocytes des follicules primordiaux d'ovaire de ratte adulte cyclique. Ann. Biol. anim. Bioch. Biophys., 18, 1333-1342.

MARIANA J. C., MEYER J. A., 1979. Application of a simulation method for a study of beginning growth in ovarian follicles. Ann. Biol. anim. Bioch. Biophys., 19, 1435-1442.

MEIER P., 1953. Variance of a weighted mean. Biometrics, 9, 59-62.

NISHIKAWA Y., 1959. Studies on reproduction in horses. Jap. Rac. Asssoc., Tokyo.

PALMER E., 1978. Control of the oestrous cycle of the mare. J. Reprod. Fert., 53, 1-11.

PALMER E., DRIANCOURT M. A., 1980 . Use of ultrasonic echography in equine gynecology. Theriogenology, 13, 203-216.

DE REVIERS M. M., MAULÉON P., 1979. Effets des hormones gonadotropes sur l'ovaire de ratte immature. Ann. Biol. anim. Bioch. Biophys., 13, 177-193.

DE REVIERS M. M., TERQUI M., 1976. Ovarian follicular development and gonadotrophin levels during prepubertal life in three strains of rat with different sensitivity to FSH. Ann. Biol. anim. Bioch. Biophys., 16, 307-311.

SHARP D. C., 1976. Cité par GINTHER O. J., 1979.

SIEGEL S., 1956. Non parametric testing for behavioural sciences. McGraw Hill, New York.

WALT M. L., STABENFELDT G. H., HUGUES J. P., NEELY D. P., BRADBURY R., 1979. Development of the equine ovary and ovulation fossa. J. Reprod. Fert., Suppl. 27, 471-477.

WOODS G. L., SCRABA S. T., GINTHER O. J., 1982. Prospects for induction of multiple ovulations and collection of multiple embryos in the mare. Theriogenologr, 17, 61-72. 